\title{
Teaching of Bioethics in Dental Graduate Programs in Brazil
}

\section{Ensino de bioética em programas de pós-graduação em Odontologia no Brasil}

\author{
Carolina Patrícia Aires* \\ Fernando Neves Hugo** \\ Pedro Luiz Rosalen*** \\ Fernanda Klein Marcondes****
}

\begin{abstract}
In the field of human research, researchers are faced with unexpected moral dilemmas, as a result of the development of technologies applied to health. Due to the great importance of this issue, our objective was to evaluate bioethics instruction in the education of researchers in Brazilian graduate programs in dentistry. Eighty-seven graduate programs in dentistry, recognized by CAPES (Coordination for the Improvement of Higher Education Personnel) were evaluated in this study. Data were extracted independently by two researchers from the CAPES website, and from the websites of the graduate programs, directly or via links to the programs available at the CAPES website. Forty-eight out of 87 programs had an ethics/bioethics course as part of their curricula. Of the graduation programs graded 5,6 or 7 by CAPES, $38 \%$ included bioethics courses, while $62 \%$ of the programs graded 3 or 4 by CAPES had bioethics courses as part of their curricula. These findings are an alert to those involved in dental research education, as they showed that, although resolution 196/96 by the National Council of Health regulating human research in Brazil was published ten years ago, bioethics instruction in Brazilian graduate programs in dentistry is still at an incipient stage. This situation indicates a need for ethics pedagogy in the education of young researchers.
\end{abstract}

DESCRIPTORS: Bioethics; Teaching; Dentistry.

\begin{abstract}
RESUMO: O desenvolvimento de tecnologias aplicadas à saúde traz dilemas morais inesperados aos profissionais de pesquisa, em relação às práticas que envolvem seres humanos. Devido à relevância deste assunto, o objetivo deste estudo foi avaliar o ensino de bioética na educação de estudantes de programas de pós-graduação em Odontologia do Brasil. Oitenta e sete programas de pós-graduação em Odontologia, avaliados pela CAPES (2001-2003), foram estudados. Os dados foram extraídos, de maneira independente, por 2 avaliadores, por meio de consulta ao sítio da CAPES e aos sítios eletrônicos dos programas, diretamente ou via links dos programas disponíveis no sítio da CAPES. Dos 87 programas, 48 apresentaram disciplina de Ética/Bioética. Trinta e oito porcento dos programas com conceitos 5, 6 e 7 da CAPES mantêm disciplinas de Bioética, enquanto $62 \%$ dos programas com conceitos 3 e 4 apresentaram conteúdos de Bioética. Desta forma, os resultados deste estudo representam um alerta para os educadores envolvidos em ensino da pesquisa odontológica. Estes resultados também mostraram que a instrução em bioética ainda é incipiente nos programas de pós-graduação em Odontologia no Brasil, ainda que a resolução 196/96 do Conselho Nacional de Saúde tenha sido publicada há dez anos. Por este motivo, seria necessário assegurar uma pedagogia ética na formação do jovem pesquisador.
\end{abstract}

DESCRITORES: Bioética; Ensino; Odontologia.

\section{INTRODUCTION}

With the development of new technologies applied to health, researchers involved in human research are faced with unexpected moral dilemmas. The lack of consolidated guidelines expresses the shortcomings in the education of researchers in the health field. The paradigm of traditional ethics is unable to offer solutions to the new situations presented by the continuous developments in science and the problems resulting from them.

According to Potter ${ }^{10}$ (1971), bioethics should be a discipline capable of tracking scientific development with ethical awareness, supposedly ex-

\footnotetext{
* MS in Dentistry; ***PhD in Pharmacology - School of Dentistry of Piracicaba, State University of Campinas.

** MS in Biomedical Gerontology, Pontifical Catholic University of Rio Grande do Sul.

**** PhD in Sciences, Institute of Biology, State University of Campinas.
} 
Aires CP, Hugo FN, Rosalen PL, Marcondes FK. Teaching of Bioethics in Dental Graduate Programs in Brazil. Braz Oral Res 2006;20(4):285-9.

empt from moral interests. Due to its multifactorial character, however, bioethics teaching represents a challenge to many educators and researchers, mainly because a bioethics course demands information from distinct areas of science and the humanities, such as philosophy, medicine, biology and anthropology. ${ }^{3}$

In Brazil, awareness of bioethics teaching was first assessed in medicine. ${ }^{3}$ The authors carried out a survey to evaluate the status of medical ethics education at Brazilian undergraduate medical schools. In dentistry, the status of bioethics education was first reported by $\operatorname{Odom}^{7}$ (1982), who assessed bioethics teaching in North American Universities during the eighties. In Brazil, however, there is no study with the aim of evaluating bioethical teaching in Dental Programs.

Although the significance of building up ethical integrity in undergraduate studies and during professional practice is clear, the dentist, as well as other health professionals, daily experiences ethical conflicts related to uncertainties inherent to the health system. Furthermore, young dental researchers, whose research frequently involves humans, constantly experience moral and ethical dilemmas. Health researchers are often asked to take scientifically relevant decisions based solely on their own innate sense. According to Almeida, Schramm ${ }^{1}$ (1999), we are at present going through a period of transition, with two competing paradigms: science and bioethics.

Since a large proportion of dental research involves human beings, it would be important to design a study to evaluate bioethics teaching in Brazilian graduate programs in dentistry, with the object of providing students with the ability to analyze ethical issues and take ethical decisions in research, and to stimulate their socio-moral development.

The aim of this study was, therefore, to make this evaluation and to contribute to the discussion about the need for ethical content in these programs.

\section{MATERIAL AND METHODS}

In this cross-sectional study, an assessment was made of 87 graduate programs in dentistry evaluated by CAPES (Coordination for the Improvement of Higher Education Personnel) during the triennium 2001-2003, with the results of the evaluation published in November, 2005. Data were extracted from the CAPES web site or from links of the graduate programs available at the CAPES web site. Graduate programs whose links were not available at the CAPES web site were searched at various university and research institution web sites, or using free internet search engines.

All data were extracted by two evaluators, independently. Discrepancies between data collected by the two evaluators were resolved by a reviewer, or by consensus. A standard extraction data sheet, especially designed for the study, listed the following information: date; evaluator's name; name of the university, institution or research center; state; administrative category (in accordance with article 19 of the Directives and Bases of the Education Act - "Lei de Diretrizes e Bases da Educação, Artigo 19"); school, faculty or institute; graduate program name; graduate program levels (in accordance with CAPES's classification); graduate program areas; graduate program web site; graduate program rating in the 2001-2003 triennial CAPES evaluation; whether or not there was a list of courses offered by the graduate program in its web site; whether or not there was a bioethics or an ethics course; duration, in number of hours, of the bioethics or ethics courses whenever they were offered; whether or not there was additional information regarding the bioethics or ethics course; reference to ethics or bioethics content in the other courses offered by the graduate program. If the information regarding ethics or bioethics teaching was not available in the graduate program web sites, it was extracted from the CAPES data base.

\section{Criteria to define the administrative category of the universities and institutions}

The administrative classification of the universities or institutions to which the graduate programs were related was based on Article 19 of the Directives and Bases of the Education Act - "Lei de Diretrizes e Bases da Educação, artigo 19". This act classifies the universities and institutions into the following administration levels: I - public, recognized as those created or incorporated, maintained or administrated by the Government; II - private, recognized as those maintained and administrated by private individuals or private corporate bodies.

\section{Criteria to classify and rate graduate programs in accordance with CAPES}

In accordance with CAPES's criteria, the graduate programs were classified as: academic Master's/ Ph.D. programs (M/P); professional or academic Master's programs (P/A); professional Master's and 
Aires CP, Hugo FN, Rosalen PL, Marcondes FK. Teaching of Bioethics in Dental Graduate Programs in Brazil. Braz Oral Res 2006;20(4):285-9.

Ph.D. programs (P/D); academic and professional Master's and Ph.D. programs (A/P/P).

After its triennial evaluation of recognized graduate programs, CAPES attributed grades ranging from 1 to 7 . Programs graded 6 or 7 were considered programs that offer Ph.D. courses of excellence, with performance equivalent to those of important international educational and research institutes, a high level of international insertion, great capacity for nucleating new research and educational groups and composed of researchers and professors that play leading roles in their respective research communities. Programs graded 5 were those with a high performance, and 5 was the highest grade attributed to programs offering only Master's courses and degrees. Programs graded 4 were those with a good performance, while programs graded 3 had a regular performance. Programs graded 1 and 2 were not recommended because they did not meet the minimum quality standards required by CAPES. The grades of all graduate programs were recorded, but only those with a grade $=$ or $>3$ were analyzed.

\section{Statistical analysis}

The data extracted from data bases and web sites were transferred to and analyzed with the SPSS $^{\circledR}$ 12.0. (SPSS Inc., Chicago, Illinois, USA). Analysis of frequency of the data was performed. Furthermore, associations were verified by means of the chi-square test. Administrative category (public or private), graduate program level (categorized as: only Master's level, academic or professional; only Ph.D. or Master's + Ph.D.) and CAPES's grades (categorized as: 3-4; 5-6-7) were set as independent variables. Existence of bioethics or ethics course in the graduate program and reference to an ethics or bioethics content in the list of courses offered in the graduate program were set as outcomes. The value set to reject the null hypothesis was $\mathrm{p}>0.05$.

\section{RESULTS}

Fifty five per cent $(\mathrm{N}=48)$ of the evaluated graduate programs had an ethics or bioethics course among the courses offered to students. Similarly, $54.0 \%(\mathrm{~N}=47)$ had an ethics or bioethics content listed in their course lists. When the data referring to the existence of an ethics or bioethics course were related to the existence of an ethics or bioethics content in the course lists, there was a significant association between these variables $($ Spearman Correlation $=0.65 ; \mathrm{p}<0.001)$.
The frequencies of public and private institutions that had ethics or bioethics courses or contents were not significantly different (chi-square test, $\mathrm{p}>0.05)$. Furthermore, there were no significant differences in the distribution of graduate program frequencies for the variables "existence of ethics or bioethics course" and "existence of an ethics or bioethics content", as regards the level of the institution (chi-square test, $\mathrm{p}>0.05$ ).

There was a significant association between the variable "existence of ethics or bioethics course" and the graduate program grade in the triennial CAPES evaluation of 2001-2003 (chi-square test, $\mathrm{p}=0.036)$. The graduate programs with the worst grades (3-4) were 1.64 times more likely (C.I. $95 \%=1.05$ to 2.55 ) to have an ethics or bioethics course offered in their graduate programs than the graduate programs with higher grades (5 to 7 ). There was, however, no association between the CAPES grades and the existence of bioethics or ethics content in the courses offered by the graduate programs (chi-square test, $\mathrm{p}>0.05$ ). When only the graduate programs rated as excellent (grades 6 and 7) were grouped and compared with the remaining graduate programs (grades 3,4 or 5), there was no difference as regards the variable "ethics or bioethics content" (Fisher Test, $p=0.33$ ). It was not possible to assess whether there were differences with regard to the existence of an ethics or bioethics course using the categorization described (6-7 or 3-4-5), because one of the cells in the $4 \times 4$ contingency table used in the Fisher test calculation had no case in it (Table 1).

\section{DISCUSSION}

The data from the present study showed that $45 \%$ of the Brazilian graduate programs in dentistry did not offer any kind of bioethics teaching. This is a high percentage, if compared with studies performed in the USA, where the percentage of dental schools that did not have a course of bioethics was only $21 \%$ fifteen years ago. ${ }^{6}$ In this context, the findings of our study suggest that there is not a great deal of concern as regards discussing bioethics in graduate student education, since only $52 \%$ and $65 \%$ of the public and private institutions, respectively, had a bioethics or ethics course in their graduate programs.

Moreover, only $38 \%$ of the graduate programs with better ratings (grades 5,6 or 7 ) had ethics or bioethics courses, while $62 \%$ of the programs with worse ratings (grades 3 or 4 ) had an ethics or bioethics course. This evidence suggests that bio- 
Aires CP, Hugo FN, Rosalen PL, Marcondes FK. Teaching of Bioethics in Dental Graduate Programs in Brazil. Braz Oral Res 2006;20(4):285-9.

TABLE 1 - Distribution of frequencies of the variables "existence of Ethics or Bioethics Discipline" and "existence of an Ethics or Bioethics content listed in the Courses" according to: administrative categories, levels and grades in the 2001-2003 CAPES triennial evaluation.

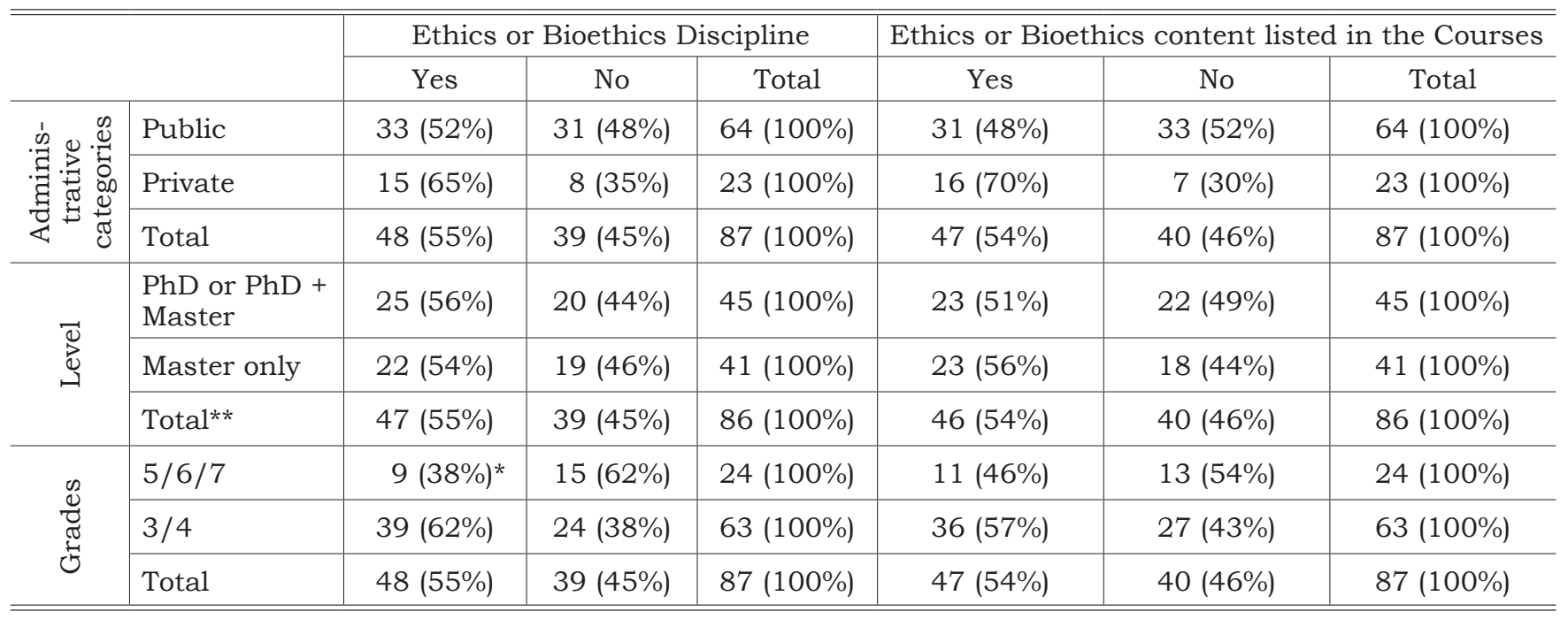

*Significantly different from the category $3 / 4, p=0.036(\mathrm{OR}=1.64,95 \% \mathrm{CI}=1.05$ to 2.55$)$, chi-square test. ${ }^{* *}$ Since one of the programs presented only the level "professional master", it was excluded from the statistical analysis on the relationship between ethics discipline/content and level of graduate programs.

ethics is more frequently discussed in "developing" graduate programs than in those considered of excellence. We have, however, not distinguished clinical and laboratorial areas, which could be interesting to evaluate in further studies. Furthermore, an interesting highlight is that the proportion of graduate programs that had ethics or bioethics contents did not differ significantly with regard to the graduate program ratings.

The mean number of course hours was 36 $( \pm 18)$ class hours (data not shown). According to Odom $^{8}$ (1988), the number of instructional hours is closely related to the appropriate content of dental ethics courses, since the optimum number of hours is dependent on the amount of time required to adequately cover the content. Unfortunately, in the present study there were no available data to support this evaluation, since only 8 courses out of 48 provided this information in their web sites.

It was not possible to evaluate the ethics or bioethics background of the professors that taught bioethics or ethics courses, by means of the CAPES data base or graduate program web sites. Although the CAPES website provides an option for the graduate program to supply this information, the vast majority of them usually do not. However, it would be interesting to analyze this data, since there is a study ${ }^{5}$ in the medical literature that evaluated 79 undergraduate medicine courses, and showed that ethics education is devoted almost exclusively to deontology. Considering that traditional ethics teaching is insufficient to cover the needs of the society, it is imperative to reformulate and broaden ethics and bioethics education.

In bioethics, decision making is considered a difficult process that requires the students to have a minimum degree of ethical development, so that they are capable of making a decision independently. According to the classical Jean Piaget studies, however, a cognitive conflict is required from the subject, meaning that it demands cognitive circumstances beyond his/her own stage of ethical development. Nevertheless, this objective will not be easily attained merely by including a static bioethics course in a graduate program. It is also necessary to include bioethical contents in the other courses of graduate programs, as well as in the docent's behavior. ${ }^{6}$

In the medical field, where ethical behavior is more frequently discussed when compared with the dental field, evidence indicates that ethically inadequate and inhumane attitudes are frequently observed, not only in health professionals, but also in docents. The inobservance of ethical principles may be easily observed in several of the health care system scenarios, including medical schools, docent-docent, docent-student and doctor-patient relationships. ${ }^{11,12}$ These pieces of evidence are important, because professors-educators represent the models the students incorporate as a pattern 
of professional behavior. Evidence from the present study indicates that the majority of the universities and institutes that offered ethics or bioethics courses also had bioethics contents as part of other courses $(r=0.65, p<0.001)$, suggesting that the graduate program docents are concerned with this issue. Data was, however, not collected with the aim of assessing the impact of docents' examples and attitudes on the academic and professional performances of the students. Future studies should address this issue by adding interviews with students to their data collection.

Although our data may cause concern, this problem is not peculiar to Brazil. Bioethicists from several countries, including Canada, Chile, Japan and USA, agree that, at present, bioethics education does not meet the needs of the societies in their countries..$^{4,7-9}$ Although bioethics education may not overcome all the irregularities that might occur in research, graduate programs should value it in such a way that it generates a positive impact on the scientific education of students.

Thus, bioethics teaching in graduate programs, particularly in the dental area, should foster the objective of educating professionals that are familiar with and capable of using the fundamental aspects of ethical behavior when interacting with

\section{REFERENCES}

1. Almeida JLT, Schramm FR. Paradigm shift, metamorphosis of medical ethics, and the rise of bioethics. Cad Saúde Pública. 1999;15(Suppl 1):15-25.

2. Brasil. Conselho Nacional de Saúde. "Termo de consentimento livre e esclarecido - TCLE". Contém as Diretrizes e Normas Regulamentadoras de Pesquisas envolvendo Seres Humanos. Resolução CNS 196/96 de 10 de outubro de 1996 [acesso 07 jul 2005]. Disponivel em: http://conselho. saude.gov.br/comissao/conep/resolucao.html..

3. Diniz D, Guilhem D. O que é bioética. São Paulo: Brasiliense; 2002.

4. Goldie J, Schwartz L, McConnachie A, Morrison J. The impact of three years' ethics teaching, in an integrated medical curriculum, on students' proposed behaviour on meeting ethical dilemmas. Med Educ. 2002;36(5):489-97.

5. Meira AR, Cunha MMSC. O ensino da ética médica em nível de graduação nas faculdades de medicina do Brasil. Rev Bras Educ Méd. 1994;18(1):7-10.

6. Miranda Sá Jr LS. Ética do professor de Medicina. Bioética. 2002;10(1):49-84. their colleagues, when performing experiments with animals and, above all, when interacting with their patients and research volunteers. This ethical behavior includes Informed Consent ${ }^{2}$ to the fullest extent to which it is related to human research.

\section{CONCLUSIONS}

The findings of the present study are an alert to those involved in dental research education, as they show that although the resolution regulating human research in Brazil was published ten years ago, bioethics instruction in Brazilian graduate programs in dentistry is still at an initial stage. Bioethics education should become a primary concern in the development of the Brazilian researcher, in order to suit his/her education to contemporary needs.

\section{ACKNOWLEDGEMENTS}

The authors gratefully acknowledge the help of the Course "Topics in Bioethics" of the Graduate Program in Dentistry (CAPES grade 6), School of Dentistry of Piracicaba, University of Campinas (UNICAMP), which made the writing of this manuscript possible. The authors thank Margery Galbraith for editing the English of the manuscript.

7. Odom JG. Formal ethics instruction in dental education. J Dent Educ. 1982;46(9):553-7.

8. Odom JG. The status of dental ethics instruction. J Dent Educ. 1988;52(6):306-8.

9. Piko BF, Kopp MS. Paradigm shifts in medical and dental education: behavioural sciences and behavioural medicine. Eur J Dent Educ. 2004;8(Suppl 4):25-31.

10. Potter VR. Bioethics. Bridge to the future. Englewood Cliffs: Prentice Hall; 1971.

11. Rego SA. A formação ética dos médicos: saindo da adolescência com a vida (dos outros) nas mãos. Rio de Janeiro: Fiocruz; 2003.

12. Romano VF. O ensino-aprendizagem da relação médico-paciente no terceiro ano médico: o relato de uma observação [Dissertação de Mestrado]. Rio de Janeiro: Instituto de Medicina Social da Universidade Estadual do Rio de Janeiro; 2001.
Received for publication on Apr 04, 2006

Sent for alterations on Jun 21, 2006

Accepted for publication on Jul 31, 2006 